\title{
アルミニウムのすきま腐食における 電気化学的ノイズとモニタリングの可能性
}

\author{
糸井康彦*, 武成 祥*, 奥山 優* \\ * 小山工業高等専門学校 物質工学科
}

\author{
Eletrochemical Noise in Crevice Corrosion of Aluminum and \\ Possibility for Its Monitoring \\ Yasuhiko Itoi*, Seisyo Take* and Masaru Okuyama* \\ * Depertment of Materials Chemistry and Bioengineering, Oyama National Colledge of Technology
}

\begin{abstract}
Possibility of the application of the electrochemial noise analysis to aluminum crevice corrosion was studied. Anodic polarization curves with various scanning rates of potential were measured for the aluminum electrode in the artificial crevice. Current noises were measured for the aluminum artificial crevice electrode at various anodic potentials. On the other hand, current noises were measured for the platinum artificial crevice electrode at various cathodic potentials. The short-circuited current noise and the potential noise of the aluminum artificial crevice electrode coupled with an external aluminum electrode were measured.

Any current noises were not obserbed in the region of the potential less noble than crevice potential $\left(E_{c}\right)$, above which the noises were generated due to the hydrogen evolution. This was verifyed by the fact for the hydrogen evolution on the platinum crevice electrode. Notable noises of synchronized short-circuited current and potential appeared after 50 minutes of immersion being due to the hydrogen evolution. Thus, the natural crevice corrosion was simulated with this short-circuited coupling cell. The potential noise will be considerd as an easy monitoring tool for these crevice corrosion detection, because the potential noise was changed with the current noise in the same period.
\end{abstract}

Key words : electrochemical noise, aluminum, crevice corrosion, artificial crevice, hydrogen evolution, synchronized, monitoring

\section{1. 緒}

著者らはこれまでに，孔食 ${ }^{1), 2)}$ ，塗膜下腐食 $\left.\left.{ }^{3)}, 4\right), 5\right)$ ，す きま腐食 ${ }^{6)}$,7), 8) に対するモニタリング法として, 電気化 学的ノイズ解析法の適用性を検討してきた。

孔食や応力腐食に対するノイズ解析に関しては既に多 〈の研究報告 9), 10) がある. 著者らは孔食に対しては, 現象とノイズパターンの関係を定性的に明らかにし，パ ワースペクトルによる解析でノイズ発生頻度とスペクト ルパラメータの関係を定量的に求めた．しかし，同じ局 部腐食であるすきま腐食に対するノイズ解析に関する研 究 11),12) は余りない. Dawson ら 13),14) は，すきま腐食発 生時のノイズに関する報告を行っているが，その中では ノイズの発生源に関する詳しい説明がされていない。 イズを定量的に解析するためには，ノイズ発生のメカニ ズムを知ることは最低限必要である.

そこで，著者らはアルミニウムのすきま腐食について ノイズ発生メカニズムを明らかにするとともに，ノイズ によるすきま腐食発生のモニタリングの可能性について 検討を加えた．自然条件下でのすきま腐食を短時間で捕 らえることは困難なので, 著者ら ${ }^{6)}$ は, 加速法の一つと して，試作した人工すきまをもつアルミニウムをアノー ド分極して，すきま腐食を発生させた。これまでの孔食

* テ323-0806 栃木県小山市中久喜 771 （771, Nakakuki, Oyama, 323-0806 Japan)
に関する結果 1), 2) から，局部腐食の種類と発生するノイ ズパターンに対応関係があることがわかったが，すきま 腐食についても同様な関係があるかどうかを明らかにす るために，電気化学的な分極法と自然系に近づけた外部 電極との短絡法を通して, すきま内で起こる電気化学的 現象を定量的に解析し, すきま腐食発生時の電気化学的 ノイズの特徴を明らかにした。

それらの結果から，自然系ですきまが形成されたとき に発生する電気化学的ノイズの検出と腐食モニタリング の可能性を検討したので報告する.

\section{2. 実 験 方 法}

\section{1 人工すきま電極の作製とアノード分極曲線測定}

試験片には，純度 $99.99 \%$, 厚さ $100 \mu \mathrm{m}$ のアルミニウ ム䇴を用いた。これをアセトンとエタノールで脱脂後, 2 枚のアクリル板との間に挟み込み，アクリル製のボル トナットにより適度なトルクで締め付けて人工のすきま を作った. Fig. 1 に人工すきまの概略図を示した。

このすきま電極を試料極とし, 対極に白金, 照合電極 に飽和銀-塩化銀電極を用いた 3 電極法で，大気開放下 で分極曲線を求めた．試験液は $0.5 \mathrm{~mol} / l$ の塩化ナトリウ 厶水溶液である. 測定には北斗電工製 HA-151 ポテンシ ヨスタットとファンクションジェネレータ HB-104 を用 い, 電位走査速度が $0.04 \sim 50 \mathrm{mV} \cdot \mathrm{min}^{-1}$ の範囲で動電位 分極を行った。 


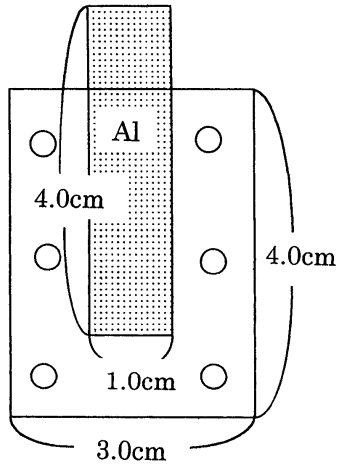

Fig. 1 A sketch of artificial crevice electrode.

2.2 すきまアルミニウム電極のアノード電流ノイズと すきま白金電極の水素発生電流ノイズの測定

アルミニウムすきま電極の動電位アノード分極曲線を 測定し，これに基づきいくつかの電位を選んで定電位分 極を行った. 分極は $-1.4 \sim+0.4 \mathrm{~V}$ の電位範囲で $24 \mathrm{~h}$ 行 い，それぞれの電流-時間曲線を求めた.

また一方，アルミニウムのすきまから発生する水素気 泡が電流ノイズを誘起するとも考えられるので，それを 実験的に模擬するために，すきま内に白金（表面積 10 $\left.\mathrm{cm}^{2}\right)$ を挟み込み, $-1.3 \sim-1.9 \mathrm{~V}$ の水素発生電位領域で カソード分極した. 本実験も, 前節と同様な実験条件で あり, 電位走查速度 $50 \mathrm{mV} \cdot \mathrm{min}^{-1}$ の動電位法により分極 を行った。

\section{3 短絡電流と短絡電位の測定}

以上は外部電源による分極実験であるが，害際の自然 系すきま腐食に近付けるために，同一のアルミニウム試 片を外部電極として設置し, すきま内部のアルミニウム 電極と短絡し，すきま内アルミニウムの電位と短絡電流 の経時変化を測定した，すきま内アルミニウム電極と外 部アルミニウム電極の面積比は $1: 100$ とし, 両者は一 定の間隔を置いて設置した。試験液は同じ $0.5 \mathrm{M}$ の NaCl 水溶液である. 電流の測定には北斗電工製 HM-104 ゼロ シャント電流計，すきま内電極の測定には北斗電工製 HA-151 ポテンショスタットと飽和銀-塩化銀電極を用 い，電位と電流の振動を記録計で求めた. Fig. 2 に測定

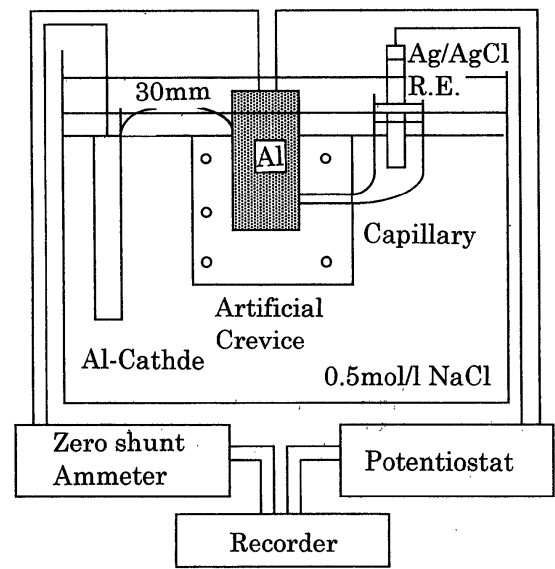

Fig. 2 Apparatus for elecrochemical noise measurement.
系の略図を示した。

$$
\text { 3. 結果 }
$$

\section{1 人工すきま電極の分極曲線の電位走査速度依存性 と電流ノイズの検出}

Fig. 3 に電位走査速度を変えた場合のアルミニウム人 エすきま電極のアノード分極曲線を示した．比較のため に開放系アルミニウム試料により孔食が発生した場合の 分極曲線についても図中に示した.

人工すきま電極の場合には，測定後，すきま部のわず かな試験液に対して $\mathrm{pH}$ 試験紙を用いて調べ，すきま内 が酸性化（pH 2〜3）していることが確かめられた，孔 食, すきま腐食ともに, 自然浸漬電位から分極後アノー ド電流の急増する電位をそれぞれ孔食電位 $\left(E_{\mathrm{p}}\right)$, すき ま腐食電位（ $\left.E_{\mathrm{c}}\right)$ とした．人工すきま電極の場合には, 電位走査速度が小さくなるにつれて， $E_{\mathrm{c}}$ は卑へシフトし た。また，すきま腐食の場合，電位走査速度が $0.06 \mathrm{mV}$. $\mathrm{min}^{-1}$ 以上では， $E_{\mathrm{c}}$ より卑な電位領域 (initiation) に表 面の不動態皮膜が破壊し再不動態化することに起因する と考えられる孔食タイプの電流ノイズが見い出された. しかし, 電位走查速度が遅い $0.04 \sim 0.06 \mathrm{mV} \cdot \mathrm{min}^{-1}$ の場 合では, $0.01 \mu \mathrm{A} / \mathrm{cm}^{2}$ 程度の小さな電流ノイズさえも検 出されなかった。また， $E_{\mathrm{c}}$ より貴な電位領域 (development）では，水素発生に起因する電流の振動が観測され た.

一方，開放系アルミニウム電極の場合，孔食電位 $E_{\mathrm{p}}$ は電位走查速度依存性を持つことなくほとんど一定であ った。

この場合には， $E_{\mathrm{p}}$ より卑な電位領域（initiation）にお いて, いずれの電位走查速度においても, 皮膜破壊と再 不動態化による電流ノイズが観測された，一方， $E_{\mathrm{p}}$ より 貴な電位領域（development）では水素発生に起因する 電流の振動が観測された. Fig. 4 に電位走查速度 0.04 $\mathrm{mV} \cdot \mathrm{min}^{-1}$ の条件下でアノード分極された時の, 2 つの 電極の $E_{\mathrm{p}}$ と $E_{\mathrm{c}}$ までの電位領域とそれより貴な電位領域 で検出される電流ノイズの様子を示した.

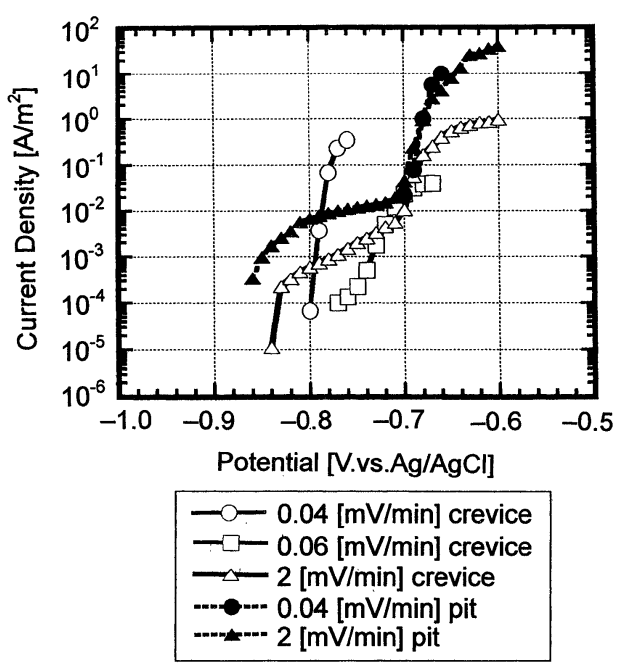

Fig. 3 Polarization curves of aluminum electrode in and out of aritificial crevice at various scaning rates of potential. 


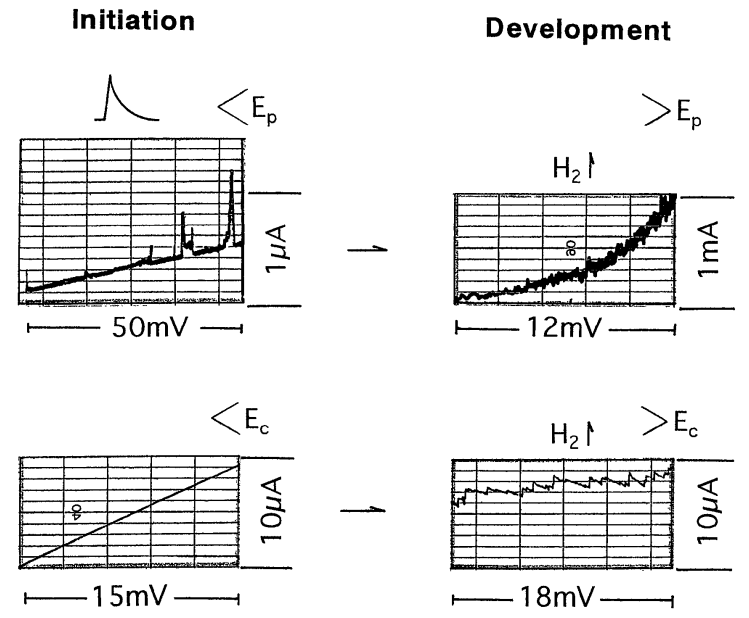

Fig. 4 Current noise generated in anodic polarization curves.

\section{2 人エすきま中のアルミニウムの定電位アノード分 極と電流ノイズ}

Fig. $5 \mathrm{a} に 0.5 \mathrm{M}$ 塩化ナトリウム水溶液中における，人 工すきま内のアルミニウムと開放系のアルミニウム電極 の電位走查速度 $50 \mathrm{mV} \cdot \mathrm{min}^{-1}$ における動電位分極曲線を 示す。電流はノイズを含む測定電流の平均值をとってい る. 腐食電位はいずれも $-1.2 \sim-1.3 \mathrm{~V}$ で比較的良好な 再現性を示している.アノード分極曲線に注目すれば, すべての電位領域で電流はすきま電極の場合の方が小さ い值を示している.いずれも $-0.7 \sim-0.75 \mathrm{~V}$ 付近に電流 の急激な増加が認められるが，開放電極の場合は孔食発 生に，人工すきま電極の場合はすきま腐食の発生に起因 するものと考えられる。次にこの腐食電位 $E_{\mathrm{c}}$ 付近より, 貴な電位領域の定電位分極を行い電流-時間曲線を求た。 Fig. $5 \mathrm{~b} に, 0 \mathrm{~V}$ で分極した時の電流の時間依存性の一例 を示す．明らかに周期的なノイズが現れている．また， ノイズは設定電位と時間によってインターバルが異な る. $10 \mathrm{~min}$ 前後の大きなゆらぎと数 $10 \mathrm{~s} \sim 1 \mathrm{~min}$ 程度の

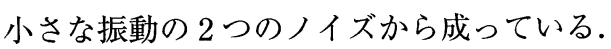

\section{3 人工すきま中の白金のカソード分極と電流ノイズ} すきま内水素発生に対する実験的なシミュレーション として，人工のすきま内の白金電極上の水素発生電流に ついて調べた. Fig. 6a に人工すきま中の白金のカソード 動電位分極曲線を示す. 水素の平衡電位は, 飽和銀-塩 化銀電極基準で, $E=-0.574 \mathrm{~V}(\mathrm{pH}$ 6) であり，水素発生 は約 $-0.6 \mathrm{~V}$ より卑な電位で起こるはずである. 分極曲線 上のそれより貴な電位領域の電流は酸素還元反応に基づ くが，開放型の白金電極と人工すきま電極と比較すると 人工すきま電極の方が電流が著しく小さい.これは，水 素発生反応では人工すきまの場合反応種が不足するため かまたは幾何学的障害が起こるためである.この結果に 基づいて-0.4〜 - $1.9 \mathrm{~V}$ の電位領域で定電位分極を行い,

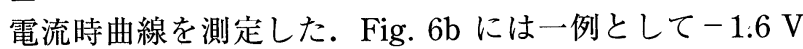
の定電位で分極して得られた電流-時間曲線上に現れた 電流振動について示した。電流ノイズは負な電流である にもかかわらず，一見して Fig. 5b のアルミニウム人工 すきま内から発生したアノード電流ノイズと同じ周期現 象を示している．すなわち，電流が急激に立ち上がりピ

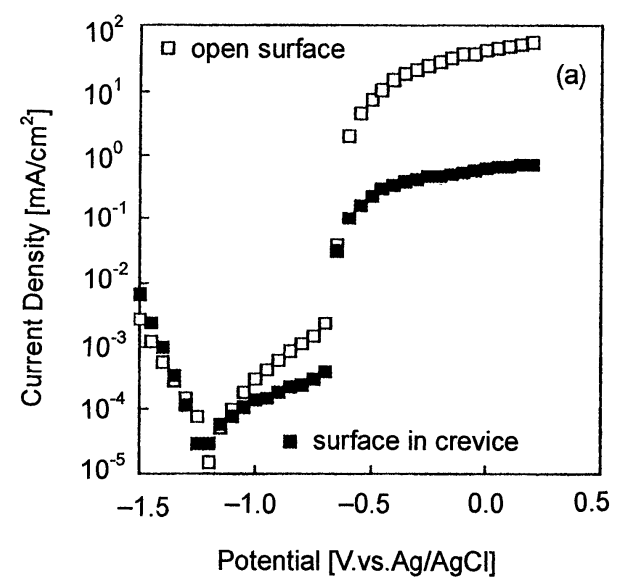

Fig.5a Polarization curves of aluminum electrode in $0.5 \mathrm{~mol} / \mathrm{l}$ $\mathrm{NaCl}$ solution.

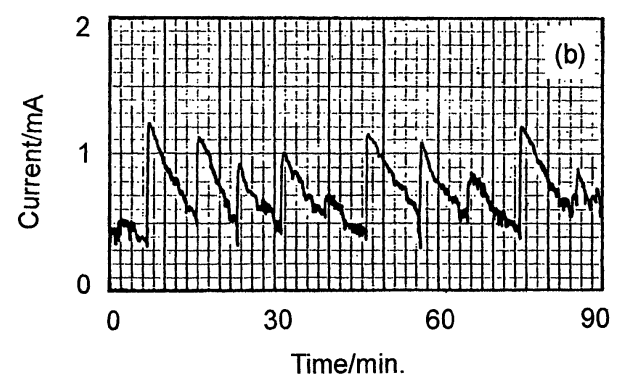

Fig. 5b Current noise of aluminum electrode in crevice polarized at $0 \mathrm{~V}$ in $0.5 \mathrm{~mol} / l \mathrm{NaCl}$ solution.

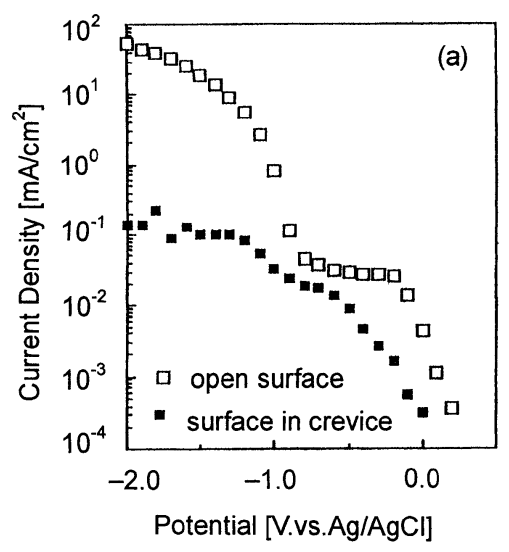

Fig. 6a Cathodic polarization curves of platinum electrode in 0.5 $\mathrm{mol} / l \mathrm{NaCl}$ solution.

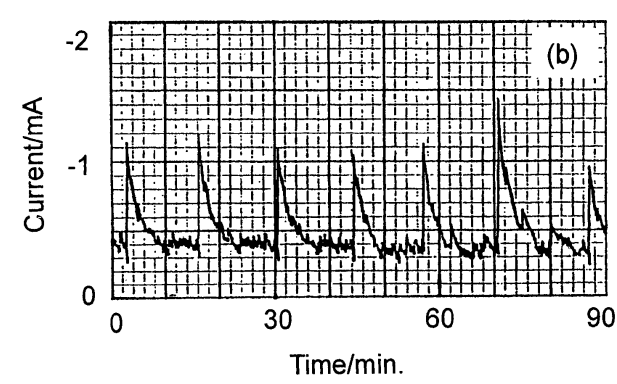

Fig.6b Current noise of platinum electrode in crevice polarized at $-1.6 \mathrm{~V}$ in $0.5 \mathrm{~mol} / \mathrm{l} \mathrm{NaCl}$ solution. 
ークに達した後減衰する形状は良く似ており，気泡が成 長して電流は徐々に減少する，ある程度成長すると，気 泡は離脱し, その時アノード電流はスパイク状に急激に 増加する．このように，人工すきま内のアルミニウム電 極と白金電極の電流の周期性が類似していることから, アルミニウムの場合もすきま内電極の表面が発生した気 泡によって遮蔽されることが, アルミニウムの溶解電流 振動の原因となっているものと考えられる。

\section{4 人工すきまセルと外部電極との間の短絡電位ノイ ズ発生と短絡電位ノイズの経時変化}

Fig. 7 に同一アルミニウム試験片と短絡された人工す きま電極の短絡電位と短絡電流の経時変化を示した。こ の場合には，電位測定はキャピラリーを用いてできるだ けすきま内部に近い電位を検出することを試みた。短絡 電流が正の值を示していることから，外部電極はカソー ド，人工すきま電極がアノードとして働いていることが わかった．このことから，このような短絡回路により， 自然系すきま腐食の模擬が可能であることがわかった. この経時変化の中で，0～ $50 \mathrm{~min}$ の間の短絡初期におい ては，電流と電位は緩やかに変化するだけで，その変化 の中には振動（ノイズ）現象は観測されなかった．この ことからも, 初期段階ではすきま腐食の進行を示唆する 電気化学的ノイズの発生がほとんど無いと考えられる. しかし， $50 \mathrm{~min}$ 以降では，電位と電流はほとんど同期し て振動していることがわかる. 電位がスパイク的に卑に なるのに対し，電流もスパイク的に上昇し，電位が緩や かに貴に回復すれば電流は徐々に減少する同期的振動が 不規則に出現した。この周期的変化については，前報 （6）で解説したように，すきま内において水素気泡が成

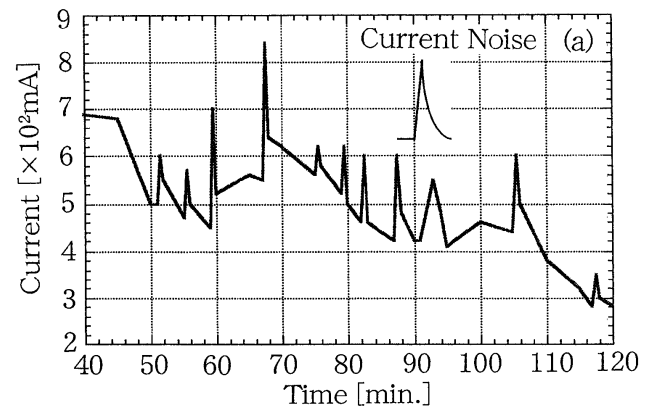

Fig. 7a Time variation of the current between the $\mathrm{Al}$ artificial crevice electerde and the external $\mathrm{Al}$ electrode.

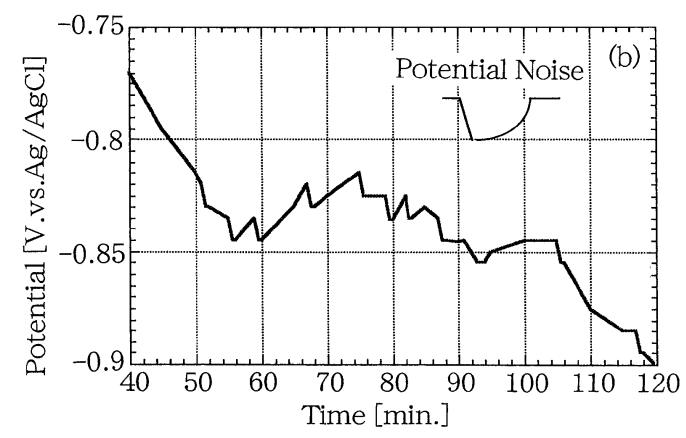

Fig. $7 \mathrm{~b}$ Time variation of the potential between the $\mathrm{Al}$ artificial crevice electerde and the external $\mathrm{Al}$ electrode.
長し離脱することに起因すると考えられる.

測定後，すきま部のわずかな試験液に対して $\mathrm{pH}$ 試験 紙を用いて調べ，すきま内が十分に酸性化（pH 2〜3） していることを確かめた．また，すきま内のアルミニウ ム試料も重量減少していることを確認した.

\section{4. 考察}

\section{1 すきま腐食電位 $E_{\mathrm{c}}$ の電位走査速度依存性}

Fig. 8 には, Fig. 3 で得られたアルミニウム人工すきま 電極における， $E_{\mathrm{c}}$ の電位走査速度依存性を示している。 また同時に，電位走査速度依存性を示さなかった開放系 のアルミニウムの孔食電位 $E_{\mathrm{p}}$ の電位走查速度依存性も 破線で示してある。

すきま腐食電位 $E_{\mathrm{c}}$ は電位走査速度が $0.08 \mathrm{mV} \cdot \mathrm{min}^{-1}$ 以上では孔食電位とほぼ等しくなるが, 電位走查速度が それより大きくなると $E_{\mathrm{c}}$ は直線的に卑になることがわ かる.

すきま腐食の反応メカニズムは，現段階では，一般に は，孔食と本質的には同一でないと認識されており，例 えば腐食発生にいたるまでの時間や発生の電位などの点 で大きく異なる.しかし, 著者らの繰り返し行った人工 すきま電極の分極実験結果から局部アノードとしてアル ミニウムが溶解し，すきま内の酸性化と気泡発生が観測 された事実から，現象論的には，以下のようにG. Wranglén ${ }^{15)}$ がアルミニウムの孔食について提案した反 応モデルに従って腐食反応は起きているものと考えられ る.

$$
\text { アノード反応 }: A l \rightarrow \mathrm{Al}^{3+}+\mathrm{e}^{-}
$$

加水分解による酸性化:

$$
\mathrm{Al}^{3+}+\mathrm{H}_{2} \mathrm{O}+\mathrm{Cl}^{-} \rightarrow \mathrm{Al}(\mathrm{OH}) \mathrm{Cl}^{+}+\mathrm{H}^{+}
$$

強酸性雲囲気でのアルミニウムの溶解とそれに伴う水素 発生が起こる.

$$
\mathrm{Al}+3 \mathrm{H}^{+}+2 \mathrm{Cl}^{-} \rightarrow(3 / 2) \mathrm{H}_{2}+\mathrm{AlCl}_{2}{ }^{+}
$$

孔食と同様に，不動態皮膜が破壊するとアルミニウム の溶解が起こり, 結果としてすきま内が酸性化し溶解反 応が加速されるものと考えられる，また，すきま腐食の 進行には $\mathrm{Al}^{3+}, \mathrm{H}^{+}, \mathrm{AlOHCl}^{+}, \mathrm{AlCl}_{2}{ }^{+}$などの物質移動 が強く関係していると考えられる. 電位走査速度が小さ くなるとすきま内の反応が充分に起こり，より酸性化し

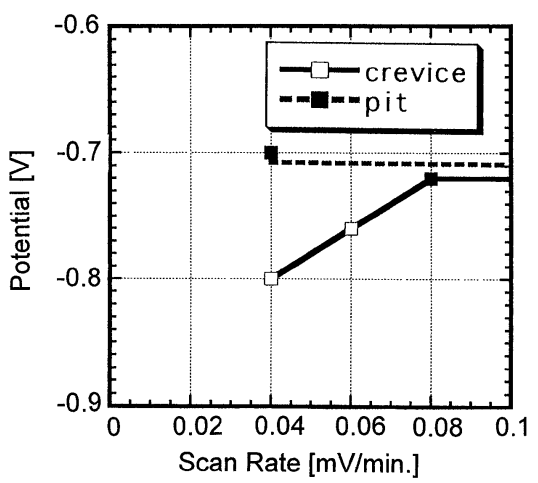

Fig. 8 Relations between the various scanning rates of potential and $E_{\mathrm{p}}, E_{\mathrm{c}}$ of aluminum electrode in and out of artificial crevice. 
やすいので, 電位走査速度が小さいほどすきま腐食電位 $E_{\mathrm{c}}$ は卑にシフトしたものと考光られる。

4.2 すきま腐食進展期の水素発生電流ノイズの発生源 一般にすきま内の溶存酸素はすきまが形成された初期 に速やかに消費され，不動態皮膜の再不動態化が踈外さ れる。さらに上述のように，孔食とほとんど同じメカ二 ズムで，塩化物イオンの濃縮と金属イオンの加水分解に よる水素イオンの増加，皮膜の全面的溶解，均一な金属 相溶解が進行すると考えられている.

しかし，すきま腐食の定義は必ずしも明確ではない. すきま内に不動態皮膜が残っている度合により，腐食が 孔食発生のタイプになる場合もあるし，また全面溶解の タイプになる場合もあると考えられる。

均一溶解という現象と電気化学的ノイズとの関係につ いては著者らも報告しているが，溶解現象に対応するノ イズは見い出されていない1).

このことは，もし，孔食タイプであれば，すきま腐食 初期の段階で, 不動態皮膜の破壊と再不動態化のノイズ が期待されるが，均一溶解であれば，ノイズを検出する ことはできない.

しかし，腐食がさらに進み，すきま内から水素が発生 する段階では電流ノイズが現れるので，電気化学的にこ れを検出することが現段階で最も可能性のあるモニタリ ングと考えられる。

Fig. 5b に示した人」すきま内のアルミニウムのアノー ド電流に現れる振動と Fig. 6b に示した人工すきま内の 白金のカソード分極時の水素発生現象による電流振動の 類似性から，人工すきま内での電流振動は水素発生に基 づく現象であると考えられる。このことを確かめるため に，人工すきまアルミニウム電極を $E_{\mathrm{c}}$ より貴な電位で 分極した時のアノード電流の振動の位置と人工寸きま内 のアルミニウム電極上からの水素気泡の離脱の観察を行 った. Fig. 9 はアルミニウムのアノード電流上の振動の 位置を示し，Fig. 10 は対応する顕微鏡写真を示してい る.

まず，No. 1 で，すきま内アルミニウム試料のエッジ 部に気泡が付着し大きく成長している，その後，電流は 振動を伴って徐々に減衰してゆくのがNo. 2 の段階であ る。大きな気泡は合体して成長し続ける。次に，No. 3 の段階では，ある瞬間に電流が急激にスパイク状に増加 するとすきま内での任意の場所から気泡が離脱し，エッ 汭部から消失するのが認められる。 その後，No. 4 の過

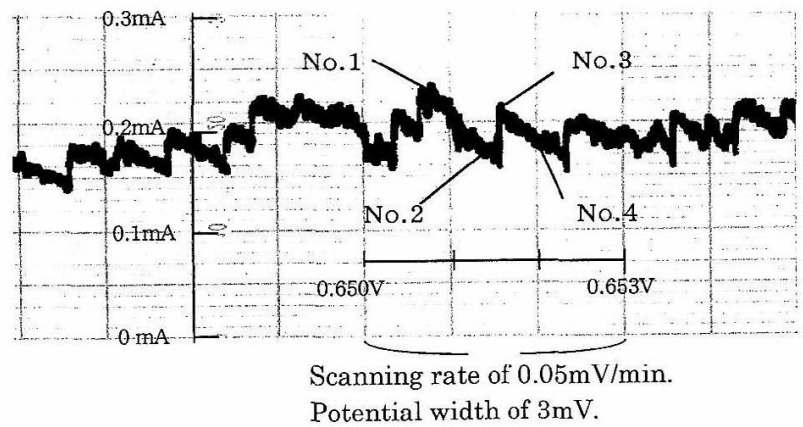

Fig. 9 Current noize on anodic polarization curve of $\mathrm{Al}$ artificial crevice electrode.
程では電流は再び減少するとともに，エッジ部で新しく 小さな気泡が成長している，気泡の成長と同時に，アル ミニゥムも溶解しているものの，成長する気泡により， アルミニウム溶解の反応サイトが遮蔽されることにより 電流が減少するものと考えられる。

気泡はある程度の大きさに達すると表面から離脱す る. 同時に,アルミニウム表面が現れ, 活性溶解と新た な水素発生が始まり, 電流の急激な増加が始まる。この ことから，アルミニウム表面の水素気泡による遮蔽効果 が電流振動に人きく影響していると考えられる.

別の実験として，すきま内にセットした実際のアルミ ニウムを, それぞれの電位に $24 \mathrm{~h}$ 設定し，アノード分極 した時の, すきま内の $\mathrm{pH}$, すきま内部での気泡, 重量 変化について評価した，腐食電位付近から貴な電位に設 定するほど，定電位設定時間が長くなるほど，すきま内 の $\mathrm{pH}$ は低下していた。 また，すきま内が酸性化するに つれて重量減少したが，すきま内は全面溶解の状態で腐 食が進行していた。 それに伴い，水素気泡の発生量も増 加していた．人工すきま中の白金についても電流の振動 と気泡の離脱について同様な関係があることを確かめて いる.

\section{3 短絡人工すきま電極からの電気化学的ノイズ発生 とモニタリングの可能性}

実験結果より，人工すきまアルミニウム電極と短絡し た外部アルミニウム電極の間では，前者がアノード，後 者がカソードとして働いていることが分かった。しかも， 浸漬後 $50 \mathrm{~min}$ 程度までは，人工すきま電極内のアルミニ ウムの電位と短絡電流ともに振動（ノイズ）が現れてい ないが，約 $50 \mathrm{~min}$ 以降では電位および電流ともにノイズ が現れ，しかも同期していることが分かった．外部アル ミニウム電極に招けるカソード反応は酸素還元反応か水 素発生反応が考えられる. pH 7 の条件では，水素電極の 平衡電位は $-0.656 \mathrm{~V}$ [vs. SSE] であり，腐食電位が一 $0.750 \mathrm{~V}$ より卑であることから, 双方の反応が考えられる. しかし $100 \mu \mathrm{A}$ 以下といった電流の大きさ，及び外部ア ルミニウム電極がすきま電極に比べ 100 倍の表面積を持 つことから，ここでは酸素還元反応が支配していると考
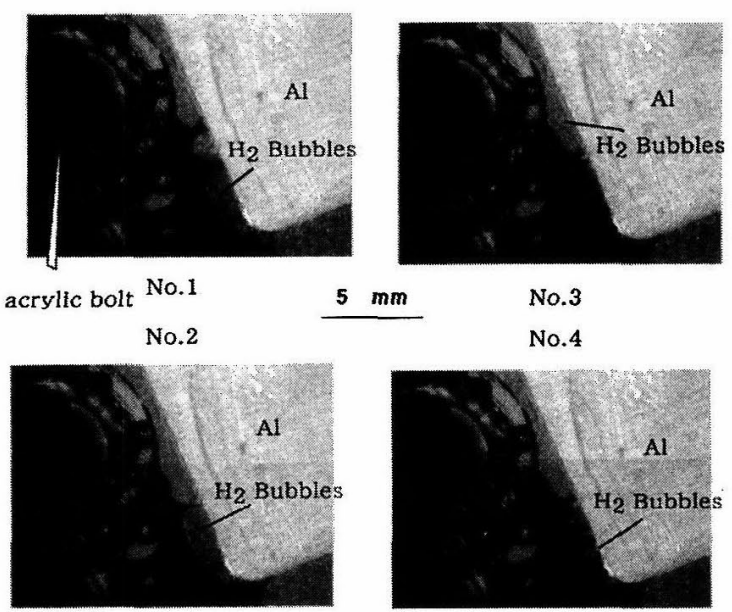

Fig.10 Microscopic photographs of hydrogen bubbles generated on $\mathrm{Al}$ surface in the artificial crevice. 
えられる。このことは，この短絡人工すきまセルは自然 系のすきま腐食を良く模擬していると考えられる。一方， すきま内のアルミニウムは塩化物イオンの濃縮や皮膜溶 解によって不動態皮膜の破壊が起こり, 反応式(1),(2)に 従って活性溶解によりすきま内が酸性化し, 電位は徐々 に卑に移行する。この時間領域では電位及び電流ともノ イズは現れないが, 電位が $-0.83 \mathrm{~V}$ に達するとノイズが 発生する. Fig. 9 の結果などを通して, このノイズは水 素発生に起因するノイズと考えられる。すなわち，反応 式(3)によるか, あるいは電位的に見ても, 水素発生電 位一 $0.574 \mathrm{~V}$ よりもはるかに卑であるので, 電気化学的な 水素発生反応が起こっている可能性がある，本人工すき ま電極による模擬実験から，すきま腐食の初期ではノイ ズが現れないが, ある程度腐食が進行し水素発生が起こ る時点では電流及び電位ともノイズが出現し，モニタリ ングできることを示している，このことは，本人工すき ま模擬実験での方法で，アルミニウム以外の金属や合金 について，すきま腐食の可否の短時間での判定が可能で あることを意味している，また，自然系のすきま腐食で は電位のモニタリングによってすきま腐食が発生したか どうかの判定も可能であることがわかった.

\section{5. 結 論}

1. 本研究に用いた人工すきまアルミニウム電極をア ノード分極すると，すきま腐食電位は電位走査速度に依 存し, 走査速度を遅くすると卑な電位を示した. しかし, $0.08 \mathrm{mV} \cdot \mathrm{min}^{-1}$ 以上では, 開放系アルミニウム電極の孔 食電位と一致した。すきま腐食電位の卑への移行は，す きま内の水素イオン濃度の増加と関係することがわかっ た.

2. 動電位法による分極実験から, 孔食の場合の電流 ノイズは孔食電位より卑な電位領域では不動態皮膜の破 壊と再不動態化に基づき, 孔食電位より貴な電位領域で は水素発生に基づく電流振動が現れるが, 人工すきま電 極の場合, すきま腐食電位より卑な電位領域では電流ノ イズは観測されなかった。すきま腐食電位より貴な電位 領域では孔食と同様に水素発生型の電流ノイズが現れ た.

3. アルミニウム人工すきまの場合と，水素発生を模
擬した白金の人工すきまの場合を比較した実験から，水 素を発生する電位領域のアルミニウムのアノード電流振 動と白金の水素発生カソード電流振動に周期性があり同 期して起こることを見い出した。このことから，アルミ ニウムのアノード電流ノイズ(振動)が, 水素気泡による アルミニウム溶解反応サイトのブロックと気泡離脱によ る溶解反応サイトの開放に起因すると考えた。

4. 人工すきま内のアルミニウムと外部アルミニウム 電極を短絡するとすきま内アルミニウムはアノードに, 外部アルミニウム電極はカソードに分極することがわか り，自然系のすきま腐食を模擬できることがわかった。 この時, すきま内アルミニウム電極の電位と短絡電流は 同期して抢り，水素発生に起因する．このことから，本 短絡セルは人工すきま腐食セルとして活用できると同様 に，すきま腐食の進展をモニタリングできることがわか った.

\section{参 考 文 献}

1) Y. Itoi and M. Okuyama, J. Technology and Education, 3, 120 (1994).

2) Y. Itoi and M. Okuyama, J. Technology and Education, 3, 128(1994).

3) Y. Itoi and M. Okuyama, Proc. Fushoku-Bosyoku '95, p. 319, JSCE (1995).

4) Y. Itoi, T. Iwamura and M. Okuyama, Proc. FushokuBoshoku '96, p.53, JSCE (1996).

5) Y. Itoi, B. Sato and M. Okuyama, Proc. 45th Jpn. Conf. Materials and Environments, p.141, JSCE (1998).

6) Y. Itoi and M. Okuyama, Electrochemistry, 66, p.1088 (1998).

7) Y. Itoi, Y. Sudo, R. Nakazato and M. Okuyama, Proc. JSCE Materials and Environments 1999, p.337, JSCE (1999).

8) Y. Itoi, S. Matsumoto and M. Okuyama, Proc. JSCE Materials and Environments 2000, p.309, JSCE (2000).

9) M. Aizawa, A. Nishikata and T. Tsuru, Proc. JSCE Materials and Environments 1999, p.325, JSCE (1999).

10) H. Inoue, K. Yamakawa, T. Kikuchi and H. Yoneda, Zairyoto-Kankyo, 45, 717 (1996).

11) S. Magaino, A. Kawaguchi, A. Hirata and T. Osaka, J. Elecrochem. Soc., 134, p.2993 (1987).

12) T. Shinohara, S. Fujimoto, N. J. Laylok, A. Masallem, H. Ezuber and R. C. Newman, J. Electrochem. Soc., 144, p.3791 (1997).

13) K. Hladky and L. Dawson, Corrosion Sci., 21, p.317 (1981).

14) K. Hladky and L. Dawson, Corrosion Sci., 22, p.231 (1982).

15) G. Wranglén, 「金属の腐食防食序論」, 化学同人, p.96 (1981).

(Manuscript received March 3 2003; in final form May 22, 2003) 